\title{
Does $\mathrm{CaCl}_{2}$ Play a Role in Improving Biomass Yield and Quality of Cardoon Grown in a Floating System under Saline Conditions?
}

\author{
Daniela Borgognone \\ Department of Agriculture, Forestry, Nature and Energy, University of \\ Tuscia, Via San Camillo De Lellis snc, 01100 Viterbo, Italy
}

Mariateresa Cardarelli

CRA-Centro di ricerca per lo studio delle relazioni tra pianta e suolo, 00184

Roma, Italy

\section{Luigi Lucini}

Institute of Environmental and Agricultural Chemistry, Università Cattolica del Sacro Cuore, 29122 Piacenza, Italy

\author{
Giuseppe Colla ${ }^{1}$ \\ Department of Agriculture, Forestry, Nature and Energy, University of \\ Tuscia, via San Camillo De Lellis snc, 01100 Viterbo, Italy
}

Additional index words. Cynara cardunculus L. var. altilis DC, medicinal plant, salinity, phenolic acids, flavonoids

\begin{abstract}
Supplemental calcium application has been reported to alleviate the detrimental effect of $\mathrm{NaCl}$-induced salinity on crop growth. Iso-molar solutions of $\mathrm{NaCl}$ and $\mathrm{NaCl}$ plus $\mathrm{CaCl}_{2}$ were used to study the osmotic and ionic effects of salinity on leaf dry biomass production and nutraceutical quality of cardoon (Cynara cardunculus L. var. altilis DC) grown in a floating system. A basic nutrient solution (control; T1) was enriched with 15 mM of $\mathrm{NaCl}+10 \mathrm{~mm}$ of $\mathrm{CaCl}_{2}$ (T2), $30 \mathrm{~mm}$ of $\mathrm{NaCl}$ (T3), $30 \mathrm{~mm} \mathrm{of} \mathrm{NaCl}+20 \mathrm{~mm} \mathrm{of} \mathrm{CaCl}_{2}$ (T4), or $60 \mathrm{~mm}$ of $\mathrm{NaCl}$ (T5). $\mathrm{NaCl}$ at $60 \mathrm{~mm}$ induced a $52 \%$ reduction of total leaf dry biomass

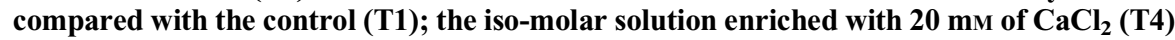
increased the total leaf dry biomass production in comparison with treatment containing $\mathrm{NaCl}$ at $60 \mathrm{~mm}$ (T5). Moreover, at moderate salinity (T2 and T3), the partial replacement of $\mathrm{NaCl}$ with $10 \mathrm{~mm}$ of $\mathrm{CaCl}_{2}$ (T2) in treatment containing $30 \mathrm{~mm}$ of $\mathrm{NaCl}$ did not help to reduce the adverse effect of $\mathrm{NaCl}$ on total leaf dry biomass production. Results of leaf mineral analysis demonstrated that the partial replacement of $\mathrm{NaCl}$ with $\mathrm{CaCl}_{2}$ reduced the accumulation of sodium and the nutrient imbalance. Nutrient solutions enriched with $\mathrm{CaCl}_{2}$ did not increase the accumulation of the osmoprotectant proline in leaves. Nutraceutical value of cardoon leaves was generally improved by saline treatments compared with the control. The regression analysis between phenolic compounds and antioxidant activity showed that total phenols and chlorogenic acid were the major determinants of antioxidant activity in cardoon leaf biomass. In conclusion, the partial replacement of $\mathrm{NaCl}$ with $\mathrm{CaCl}_{2}$ improved the leaf dry biomass production of cardoon only at the highest salinity levels with a limited effect on nutraceutical quality of leaves.
\end{abstract}

In recent decades, the reduction of fresh water sources coupled with an increase in population and in agricultural production overall led to the use of lower quality and

Received for publication 15 July 2014. Accepted for publication 19 Oct. 2014

This work is part of the Daniela Borgognone $\mathrm{PhD}$ program in Horticulture at the Tuscia University, Italy.

This work was funded by the Italian Ministry of Agricultural, Food and Forestry Policies (MiPAAF), OIGA-Project "Innovative technologies for the biomass production of artichoke and cardoon to be used for the extraction of nutraceutical compounds (PRO. BIO.CA)" (D.M. n. 29627/7818/10 of 29 Dec. 2010). ${ }^{1}$ To whom reprint requests should be addressed; e-mail giucolla@unitus.it. a plant's secondary metabolism improving antioxidant level (e.g., polyphenolic compounds, anthocyanins, $\alpha$-tocopherol, ascorbate, and glutathione) of crops (Sreenivasulu et al., 2000). An increased antioxidant content was found in crops irrigated with saline waters under soil culture conditions, e.g., chamomile (Matricaria recutita L.) (Baghalian et al., 2008), as well as in soilless greenhouse cultures, e.g., Aloe spp. (Aloe barbadensis Miller and Aloe arborescens Miller) (Cardarelli et al., 2013), broccoli (Brassica oleracea L.) (Dominguez-Perles et al., 2011), and cucumber (Cucumis sativus L.) (Colla et al., 2013a).

Cultivated cardoon, recently classified as a salt-tolerant medicinal plant rich in polyphenolic compound (Ksouri et al., 2012), is a perennial herbaceous plant that has been grown from ancient times in Mediterranean areas, mainly Italy, Spain, and the south of France. Traditionally, cardoon is cultivated for the fleshy leaf petioles used to prepare typical dishes. However, cardoon is also used as cheese rennet (Veríssimo et al., 1995) and in pharmacological and nutraceutical preparations (Fernández et al., 2006). Cynara leaf extracts have been used since ancient times for hepatobiliar system regulation and today a wide range of medicinal properties is recognized such as antioxidant effects (Kukíc et al., 2008; Miccadei et al., 2008). The antioxidant capacity of cardoon extracts was found to be strongly dependent on the qualitative and quantitative phenolic profile (Pandino et al., 2011).

A previous study indicated that the application of moderate salinity stress $(30 \mathrm{~mm}$ of $\mathrm{NaCl}$ ) was successful in improving biomass quality of cardoon grown in a floating system (Colla et al., 2013b). However, solution enriched with $30 \mathrm{~mm}$ of $\mathrm{NaCl}$ improved the antioxidant production in cardoon leaves at the expense of the biomass yield, whereas the use of a solution enriched with $30 \mathrm{~mm}$ of $\mathrm{CaCl}_{2}$ enhanced the biomass quality only in the long term without a detrimental effect on biomass yield (Borgognone et al., 2013). The addition of supplemental calcium $(\mathrm{Ca})$ to irrigation water was found to mitigate the adverse effects of salinity on other crops [e.g. strawberry (Khayyat et al., 2011) or Cichorium intybus L. (Arshi et al., 2010)]. Starting from these considerations, we hypothesized that application of solutions enriched with both $\mathrm{NaCl}$ and $\mathrm{CaCl}_{2}$ salts could reduce the detrimental effect of $\mathrm{NaCl}$ on leaf biomass accumulation and improve the nutraceutical value of cardoon biomass already after shortterm exposure to salinity. The objectives of this study were: 1) to evaluate if $\mathrm{CaCl}_{2}$ can mitigate the detrimental effect of $\mathrm{NaCl}$ salinity on leaf dry biomass yield; 2) to understand if $\mathrm{CaCl}_{2}$ can affect the polyphenol content in cardoon leaves under $\mathrm{NaCl}$ salinity stress; and 3) to study the mechanisms related to $\mathrm{CaCl}_{2}$ effects.

\section{Material and Methods}

Plant materials, growth conditions, and treatments. The experiment was conducted in 
Spring 2013 in a $300-\mathrm{m}^{2}$ polymethylmethacrylate greenhouse at the Experimental Farm of Tuscia University (lat. $42^{\circ} 25^{\prime} \mathrm{N}$, long. $12^{\circ} 08^{\prime} \mathrm{E}$, altitude $310 \mathrm{~m}$ ). The daily temperature of the greenhouse was maintained between 12 and $30{ }^{\circ} \mathrm{C}$ by forced ventilation and day/night relative humidity was 55\%/85\%. Plants were grown under natural light conditions.

Photosynthetically active radiation above the canopy was measured using a LI-COR quantum sensor (LI-190SA, Lincoln, NE). The average photosynthetically active radiation during the growing cycle was $775 \mathrm{umol} \cdot \mathrm{m}^{-2} \cdot \mathrm{s}^{-1}$.

Seeds of a cardoon cultivar Bianco Avorio (La Semiorto Sementi, Lavorate di Sarno, Italy) were sown on 7 Mar. 2013 in a floating system (Borgognone et al., 2013). The composition of the basic nutrient solution was 13 $\mathrm{mmol} \cdot \mathrm{L}^{-1} \mathrm{NO}_{3}-\mathrm{N}, 1 \mathrm{mmo} \cdot \mathrm{L}^{-1} \mathrm{NH}_{4}-\mathrm{N}, 1.75$ $\mathrm{mmol} \cdot \mathrm{L}^{-1}$ sulfur, $1.5 \mathrm{mmol} \cdot \mathrm{L}^{-1}$ phosphorus (P), $5 \mathrm{mmol} \cdot \mathrm{L}^{-1}$ potassium $(\mathrm{K}), 4.5 \mathrm{mmol} \cdot \mathrm{L}^{-1}$ $\mathrm{Ca}, 2 \mathrm{mmol} \cdot \mathrm{L}^{-1}$ magnesium, $1 \mathrm{mmol} \cdot \mathrm{L}^{-1} \mathrm{Na}$, $1 \mathrm{mmol} \cdot \mathrm{L}^{-1}$ chloride $(\mathrm{Cl}), 20 \mu \mathrm{mol} \cdot \mathrm{L}^{-1}$ iron, $9 \mu \mathrm{mol} \cdot \mathrm{L}^{-1}$ manganese, $0.3 \mu \mathrm{mol} \cdot \mathrm{L}^{-1}$ copper, $1.6 \mu \mathrm{mol} \cdot \mathrm{L}^{-1}$ zinc, $20 \mu \mathrm{mol} \cdot \mathrm{L}^{-1}$ boron, and $0.3 \mu \mathrm{mol} \cdot \mathrm{L}^{-1}$ molybdenum with an electrical conductivity of $2 \mathrm{dS} \cdot \mathrm{m}^{-1}$. The experiment treatments were five nutrient solutions, a basic nutrient solution as a control and four saline solutions (with two different total ion concentrations) obtained by adding to the basic nutrient solution different amounts of $\mathrm{NaCl}$ and $\mathrm{CaCl}_{2}$ (Table 1). Treatments started $29 \mathrm{~d}$ after sowing (DAS) at the two-true leaf stage. The $\mathrm{pH}$ of the nutrient solutions in all treatments was $6 \pm 0.3$. The nutrient solutions were completely renewed weekly and prepared using deionized water. The treatments were arranged in a randomized complete block design with three replicates per treatment. Each plot had an area of $0.1815 \mathrm{~m}^{2}$ with 84 plants.

Biomass determination. All plants of cardoon, except for border plants, were mowed 70 , and 95 DAS. Leaves were harvested when the plant height reached 20 to $25 \mathrm{~cm}$. At each three times during the growing cycle at 48 ,

harvest, the leaf tissues were dried in a forcedair oven at $60{ }^{\circ} \mathrm{C}$ for $72 \mathrm{~h}$ for biomass determination. The material of each harvest was used for mineral and quality analysis.

Mineral analysis. The mineral analysis was performed separately for each replicate sample of dried tissues. The dried leaf tissues were ground in a Wiley mill to pass through a 20-mesh screen, then $0.5 \mathrm{~g}$ samples were analyzed for the following macronutrients: nitrogen $(\mathrm{N}), \mathrm{P}, \mathrm{K}, \mathrm{Ca}, \mathrm{Na}$, and $\mathrm{Cl}$. Nitrogen concentration was determined after mineralization with sulfuric acid by the Kjeldahl method (Bremner, 1965). Phosphorus, K, $\mathrm{Ca}$, and $\mathrm{Na}$ were determined by dry-ashing at $400{ }^{\circ} \mathrm{C}$ for $24 \mathrm{~h}$, dissolving the ash in $\mathrm{HNO}_{3}$ $(1: 20 \mathrm{w} / \mathrm{v})$, and assaying the solution obtained using an inductively coupled plasma emission spectrophotometer (ICPIris; ThermoOptek, Milan, Italy) (Karla, 1998). Chloride ion concentration was determined by titration with $\mathrm{AgNO}_{3}$ in the presence of $\mathrm{K}_{2} \mathrm{CrO}_{4}$ (Eaton et al., 1995).

Nitrate concentration in dry leaves of cardoon was analyzed using the salicylic acid-sulfuric acid method (Cataldo et al., 1975) by spectrophotometry (Helios Beta, Spectrophotometer; Thermo Electron Corporation, U.K.).

Evaluation of antioxidant activity. One hundred milligrams of each dried leaf sample was extracted sequentially three times in 10,5 , and $5 \mathrm{~mL}$ of fresh ethanol/water $(80: 20 \mathrm{v} / \mathrm{v})$ containing $1 \%$ of $\mathrm{HCl} 37 \%$, respectively (total volume $25 \mathrm{~mL}$ ). The extraction mixture was stirred for $10 \mathrm{~min}$ and then solids were removed by centrifugation $(503 \times g, 5 \mathrm{~min})$. The total content of phenolic compounds in each extract was determined by the Folin-Ciocalteu method (Singleton and Rossi, 1965) and results were expressed as gallic acid equivalents (milligrams gallic acid/gram dry weight). The Folin reagent and the salts for analysis were reagent-grade materials from Sigma Aldrich, Milan, Italy.

Total flavonoids were determined following the colorimetric aluminum chloride

Table 1. Treatments tested during the trial: salt concentrations added to the basic nutrient solution, total ion concentration $\left(\mathrm{Na}^{+}, \mathrm{Ca}^{++}\right.$, and $\left.\mathrm{Cl}^{-}\right)$, and $\mathrm{EC}$ values of solutions.

\begin{tabular}{lcccc}
\hline Treatments & $\mathrm{NaCl}(\mathrm{mM})$ & $\mathrm{CaCl}_{2}(\mathrm{mM})$ & Total ion concn $(\mathrm{mM})$ & $\mathrm{EC}\left(\mathrm{dS} \cdot \mathrm{m}^{-1}\right)$ \\
\hline T1 & 0 & 0 & 0 & 2.0 \\
T2 & 15 & 10 & 60 & 4.6 \\
T3 & 30 & 0 & 60 & 4.6 \\
T4 & 30 & 0 & 120 & 6.8 \\
T5 & 60 & 0 & 120 & 6.8 \\
\hline
\end{tabular}

$\mathrm{EC}=$ electrical conductivity.

Table 2. Effects of $\mathrm{NaCl}$ and $\mathrm{CaCl}_{2}$ on leaf dry biomass of cardoon harvested at different days after sowing (DAS) and on total leaf dry biomass.

\begin{tabular}{lcccr}
\hline & \multicolumn{4}{c}{ Leaf dry biomass $(\mathrm{g} / \mathrm{plant})$} \\
\cline { 2 - 5 } Treatment & $48 \mathrm{DAS}$ & $70 \mathrm{DAS}$ & $95 \mathrm{DAS}$ & Total \\
\hline T1 & $0.76 \mathrm{a}$ & $1.14 \mathrm{a}$ & $2.67 \mathrm{a}$ & $4.57 \mathrm{a}$ \\
T2 & $0.63 \mathrm{ab}$ & $0.78 \mathrm{~b}$ & $2.12 \mathrm{ab}$ & $3.53 \mathrm{~b}$ \\
T3 & $0.61 \mathrm{ab}$ & $0.72 \mathrm{~b}$ & $1.84 \mathrm{bc}$ & $3.17 \mathrm{~b}$ \\
T4 & $0.67 \mathrm{a}$ & $0.79 \mathrm{~b}$ & $1.75 \mathrm{bc}$ & $3.21 \mathrm{~b}$ \\
T5 & $0.51 \mathrm{~b}$ & $0.58 \mathrm{~b}$ & $1.10 \mathrm{c}$ & $2.19 \mathrm{c}$ \\
Significance $^{\mathrm{z}}$ & $*$ & $* *$ & $*$ & $* *$ \\
\hline
\end{tabular}

z*, **Significant at $P \leq 0.05$ and 0.01 , respectively. Different letters within each column indicate significant differences according to Duncan's multiple range test $(P=0.05)$. method (Dutta and Maharia, 2012) and results were expressed as quercetin (reagent grade from Sigma Aldrich, Milan, Italy) equivalents (milligrams quercetin/gram dry weight).

The antioxidant activity was determined by ferric-reducing ability of plasma (FRAP) assay following the method of Pellegrini et al. (2003). Results were expressed as $\mu \mathrm{mol} \mathrm{FeSO}$ (reagent grade from Sigma Aldrich)/gram dry weight.

The method previously adopted by Colla et al. (2013b) was followed to determine caffeoylquinic acids [1,3-di-O-caffeoylquinic acid (cynarin), 3-O-caffeoylquinic acid (chlorogenic acid), and caffeic acid] and flavonoids (apigenin, luteolin, and luteolin-7-glucoside) by liquid chromatography followed by tandem mass spectroscopy with an electrospray ionization source. Pure caffeoylquinic acids and flavonoids for calibrations were purchased as certified reference materials from Sigma (St. Louis, MO). Individual stock solutions $\left(500 \mu \mathrm{g} \cdot \mathrm{mL}^{-1}\right)$ were prepared in pure methanol with sonication and stored at $-30{ }^{\circ} \mathrm{C}$ for up to $5 \mathrm{~d}$. Working standard solutions were prepared daily in amber glass flasks by diluting combined aliquots of the stock solutions in the high-performance liquid chromatography mobile phase.

Proline analysis. The third and fourth leaves from the apical shoot of four plants per plot were frozen immediately in liquid $\mathrm{N}$ at each harvest $(48,70$, and 95 DAS). The method of Bates et al. (1973) was adopted to determine the free proline content by spectrophotometry (Helios Beta, Spectrophotometer; Thermo Electron Corporation). Proline concentration was calculated on a fresh weight basis using L-proline for the standard curve.

Statistical analysis. All data were subjected to analysis of variance (ANOVA) using SPSS 14 for Windows (SPSS Inc., Chicago, IL). Duncan's multiple range test was performed at $P=0.05$ on each of the significant variables measured. A significant level of ANOVA was reported for $P \leq 0.05$, 0.01 , and 0.001 . Regression analyses were conducted to identify relationships between FRAP and total phenols, total flavonoids, and target polyphenols in cardoon leaves.

\section{Results}

Leaf dry biomass. The addition of different concentrations of $\mathrm{NaCl}$ and $\mathrm{CaCl}_{2}$ to the nutrient solution affected the biomass production (Table 2). At 48 DAS a significant reduction of biomass was observed in $\mathrm{T} 5$ treatment. At 70 DAS, the addition of $\mathrm{NaCl}$ with or without $\mathrm{CaCl}_{2}$ (T2, T3, T4, and T5) caused a decrease of leaf biomass compared with T1 (control) for both iso-molar concentrations. At 95 DAS, T2 was not significantly different from $\mathrm{T} 1$, whereas $\mathrm{T} 3$, T4, and $\mathrm{T} 5$ induced a significant reduction of leaf biomass. Total leaf biomass was significantly reduced by $52 \%$ in $\mathrm{T} 5$ compared with $\mathrm{T} 1$, whereas $\mathrm{T} 4, \mathrm{~T} 3$, and $\mathrm{T} 2$ caused a reduction of $30 \%, 30 \%$, and $23 \%$, respectively. 
Mineral content. Saline treatments did not affect total $\mathrm{N}$ and $\mathrm{P}$ content in leaves (data not shown). Treatments significantly affected $\mathrm{K}$ content in leaves (Table 3). Generally, T5 treatment caused the higher reduction of $\mathrm{K}$ content in comparison with the control with a decrease percentage of $35 \%, 47 \%$, and $49 \%$ at 48, 70, and $95 \mathrm{DAS}$, respectively. The decrease of $\mathrm{K}$ content in T4, T3, and T2 treatment with respect to T1 treatment was $20 \%, 25 \%$, and $17 \%$ at 48 DAS, and of $33 \%$, $36 \%$, and $21 \%$ at 70 DAS, respectively. At 95 DAS, T2, T3, and T4 did not decrease significantly the $\mathrm{K}$ content compared with T1 treatment. At 48 DAS, T3 and T5 caused a reduction of the leaf $\mathrm{Ca}$ content by $31 \%$ and $41 \%$, respectively, compared with $\mathrm{T} 1$ treatment (Table 3). At $70 \mathrm{DAS}$, a reduction of $\mathrm{Ca}$ content by $34 \%$ and $46 \%$ was observed in $\mathrm{T} 3$ and $\mathrm{T} 5$ treatments, respectively, in comparison with T1 treatment. On the contrary, T2 and $\mathrm{T} 4$ induced an increase of $\mathrm{Ca}$ content by $18 \%$ and $31 \%$, respectively, in comparison with T1. At 95 DAS, the highest Ca content was detected in T2 treatment followed by $\mathrm{T} 4>\mathrm{T} 1>\mathrm{T} 3>\mathrm{T} 5$. At 48 and $70 \mathrm{DAS}$, all saline treatments caused an increase of leaf $\mathrm{Na}$ content compared with the control in the following order: T5 $>$ T3 $>$ T4 $>$ T2 (Table 3). At 95 DAS, the highest $\mathrm{Na}$ content in leaves was observed in T5 treatment. Intermediate contents of $\mathrm{Na}$ were observed in the other saline treatments (T2, T3, and T4). At 48, 70, and 95 DAS, leaf nitrate content was significantly reduced in all saline treatments compared with the control (Table 3 ).

At 48,70 , and 95 DAS, leaf chloride content increased in response to saline treatments in comparison with the control (Table $3)$. At $48 \mathrm{DAS}$, the highest $\mathrm{Cl}$ content was recorded in T4 and T5 treatments. At 70 and 95 DAS, all saline treatments increased similarly the leaf $\mathrm{Cl}$ content in comparison with $\mathrm{T} 1$ treatment.

Proline content. Proline concentration in leaves of cardoon was significantly affected by treatments (Fig. 1). At 48 and 95 DAS, proline content of leaves was higher in T5 and $\mathrm{T} 4$ treatments than in $\mathrm{T} 1$ treatment. At 70 DAS, leaf proline content was increased in all saline treatments in comparison with the control treatment (T1).

Total phenolics, total flavonoids, antioxidant activity, and target polyphenols. A significant effect of treatments was recorded on total phenolics (TPs), total flavonoids (TFs), and antioxidant activity (FRAP) of cardoon leaves (Table 4).

At 48 DAS, T2, T3, and T5 induced an increase of TP compared with the control treatment $\mathrm{T} 1 \times 38 \%, 42 \%$, and $26 \%$, respectively. At 48 DAS, TF content was highest in T3 and T5 treatments with an increase of $520 \%$ and $370 \%$, respectively. Similarly, FRAP increased with saline treatments and the highest values were recorded with $\mathrm{T} 2$ and $\mathrm{T} 3$ treatments. At 70 and $95 \mathrm{DAS}$, all saline treatments enhanced TP, TF, and FRAP of cardoon leaves in comparison with the $\mathrm{T} 1$ treatment.

Caffeic acid, chlorogenic acid, and cynarin were detected in cardoon leaves with significant differences among treatments (Table 5).

At 48, 70, and 95 DAS, the highest caffeic acid content was recorded in $\mathrm{T} 5$ treatment. At 48,70 , and 95 DAS, chlorogenic acid content was enhanced in all saline treatments compared with the control (T1). Moreover, at 95 DAS, the highest chlorogenic acid content was recorded in $\mathrm{T} 2, \mathrm{~T} 4$, and $\mathrm{T} 5$ with an increase of $336 \%, 391 \%$, and $364 \%$ in comparison with $\mathrm{T} 1$ treatment, respectively.

At 48 and 70 DAS, leaf cynarin content was highest in all saline treatments, whereas at 95 DAS, the highest cynarin content was recorded in T5 with an increase of $425 \%$ in comparison with $\mathrm{T} 1$ treatment.

Flavonoids such as apigenin, luteolin, and luteolin-7-glucoside were also detected in cardoon leaves, but no significant effects of treatments were observed (data not shown).

Linear regression analysis showed an increase of FRAP as a function of total phenol content in cardoon leaves (Fig. 2). A significant positive correlation was also found between FRAP and chlorogenic acid (Fig. 2 ), whereas weak correlations between FRAP and total flavonoids $\left(R^{2}=0.55\right)$, cynarin $\left(R^{2}=\right.$ $0.15)$, and luteolin $\left(R^{2}=0.54\right)$ were recorded (data not shown).

\section{Discussion}

Osmotic versus ionic effect. The use of iso-osmotic saline solutions with different ionic composition can help in discriminating the effects of specific ion toxicities during salt stress (Navarro et al., 2003).

Because salinity often leads to a significant reduction of $\mathrm{Ca}$ activity in solution, the addition of supplemental Ca to irrigation water represents an interesting approach to reduce the detrimental effects of $\mathrm{NaCl}$ salinity on crops (Munns and Tester, 2008).

At the highest level of salinity (T4 and T5 treatments), T5 showed a more detrimental effect on biomass production than the iso-osmotic treatment with $\mathrm{CaCl}_{2}$ (T4) indicating that cardoon response to a higher level of salinity was mainly the result of ionic effects. Calcium addition showed a beneficial effect on biomass production at the highest concentration of salts, where the ionic effect of salinity prevailed. Calcium can mitigate the detrimental ionic effect of salinity rather than the osmotic one helping to preserve the structural and functional integrity of plant membranes, stabilize cell wall structures, regulate ion transport and selectivity, and control ion-exchange behavior as well as cell wall enzyme activities (Rengel, 1992).

On the contrary, at moderate salinity (T2 and $\mathrm{T} 3$ treatments), there were no significant differences on leaf dry biomass production between the two equimolar solution treatments (T2 and T3) indicating that cardoon response to moderate salinity was mainly caused by the osmotic effect. Therefore, at moderate salinity, the partial replacement of $\mathrm{Na}$ with $\mathrm{Ca}$ did not help to mitigate the detrimental effect of osmotic stress on leaf dry biomass production. Silva et al. (2008) studied the effect of $\mathrm{NaCl}$ treatments at 30 and $60 \mathrm{~mm}$ in comparison with two iso-osmotic nutrient concentrations in pepper plants (Capsicum annuum L.) and they concluded that at the highest salt concentration, plant stress is mainly the result of ions toxicity, whereas at the lowest salinity level, the osmotic effect prevailed.

Some authors suggested that Ca can help to mitigate also the osmotic effect of salinity through the accumulation of organic solutes such as proline and glycinebetaine (Girija et al., 2002). Proline is a compatible solute involved in osmotic adjustment and acts as a non-toxic osmotic solute stabilizing the structure of macromolecules and organelles in plants subjected to salt stress (Munns and Tester, 2008; Renault and Affifi, 2009). $\mathrm{CaCl}_{2}$ was found to mitigate the $\mathrm{NaCl}$-induced stress through the enhancement of proline accumulation in many plant species [e.g. Cicorium intybus L. (Arshi et al., 2010), Linum usitatissiumum L. (Nasir Khan et al., 2010), and

Table 3. Effect of saline treatments on potassium $(\mathrm{K})$, calcium $(\mathrm{Ca})$, sodium $(\mathrm{Na})$, nitrate $\left(\mathrm{NO}_{3}\right)$, and chloride $(\mathrm{Cl})$ content in leaves of cardoon at 48,70 , and $95 \mathrm{~d}$ after sowing (DAS).

\begin{tabular}{|c|c|c|c|c|c|c|c|c|c|c|c|c|c|c|c|}
\hline \multirow[b]{4}{*}{ Treatment } & \multicolumn{15}{|c|}{ Mineral element (g. $\mathrm{kg}^{-1}$ dry wt) } \\
\hline & \multicolumn{3}{|c|}{$\mathrm{K}$} & \multicolumn{3}{|c|}{$\mathrm{Ca}$} & \multicolumn{3}{|c|}{$\mathrm{Na}$} & \multicolumn{3}{|c|}{$\mathrm{NO}_{3}$} & \multicolumn{3}{|c|}{$\mathrm{Cl}$} \\
\hline & 48 & 70 & 95 & 48 & 70 & 95 & 48 & 70 & 95 & 48 & 70 & 95 & 48 & 70 & 95 \\
\hline & DAS & DAS & DAS & DAS & DAS & DAS & DAS & DAS & DAS & DAS & DAS & DAS & DAS & DAS & DAS \\
\hline T1 & $51.8 \mathrm{a}$ & $50.9 \mathrm{a}$ & $46.6 \mathrm{a}$ & $12.4 \mathrm{a}$ & $13.1 \mathrm{~b}$ & $12.8 \mathrm{c}$ & $1.8 \mathrm{e}$ & $1.1 \mathrm{e}$ & $1.1 \mathrm{c}$ & $16.2 \mathrm{a}$ & $12.3 \mathrm{a}$ & $15.2 \mathrm{a}$ & $22.1 \mathrm{c}$ & $22.8 \mathrm{~b}$ & $15.1 \mathrm{~b}$ \\
\hline $\mathrm{T} 2$ & $43.2 \mathrm{~b}$ & $40.3 \mathrm{~b}$ & $40.1 \mathrm{a}$ & $12.4 \mathrm{a}$ & $15.5 \mathrm{a}$ & $18.3 \mathrm{a}$ & $10.6 \mathrm{~d}$ & $9.5 \mathrm{~d}$ & $12.5 \mathrm{~b}$ & $6.2 \mathrm{bc}$ & $3.1 \mathrm{~b}$ & $5.7 \mathrm{~b}$ & $55.5 \mathrm{~b}$ & $70.2 \mathrm{a}$ & $72.3 \mathrm{a}$ \\
\hline T3 & $38.9 \mathrm{c}$ & $32.5 \mathrm{bc}$ & $36.4 \mathrm{a}$ & $8.6 \mathrm{~b}$ & $8.7 \mathrm{c}$ & $8.8 \mathrm{~d}$ & $22.8 \mathrm{~b}$ & $20.8 \mathrm{~b}$ & $21.2 \mathrm{~b}$ & $7.5 \mathrm{~b}$ & $4.6 \mathrm{~b}$ & $6.1 \mathrm{~b}$ & $58.2 \mathrm{~b}$ & $69.3 \mathrm{a}$ & $61.1 \mathrm{a}$ \\
\hline $\mathrm{T} 4$ & $41.6 \mathrm{bc}$ & $33.9 \mathrm{bc}$ & $37.0 \mathrm{a}$ & $13.9 \mathrm{a}$ & $17.1 \mathrm{a}$ & $15.6 \mathrm{~b}$ & $12.4 \mathrm{c}$ & $12.6 \mathrm{c}$ & $12.5 \mathrm{~b}$ & $5.0 \mathrm{c}$ & $3.9 \mathrm{~b}$ & $4.0 \mathrm{~b}$ & $62.7 \mathrm{ab}$ & $68.2 \mathrm{a}$ & $70.1 \mathrm{a}$ \\
\hline $\mathrm{T} 5$ & $33.5 \mathrm{~d}$ & $27.1 \mathrm{c}$ & $23.7 \mathrm{~b}$ & $7.3 \mathrm{~b}$ & $7.1 \mathrm{c}$ & $6.3 \mathrm{e}$ & $31.0 \mathrm{a}$ & $29.3 \mathrm{a}$ & $33.4 \mathrm{a}$ & $5.6 \mathrm{bc}$ & $3.9 \mathrm{~b}$ & $3.7 \mathrm{~b}$ & $68.3 \mathrm{a}$ & $74.5 \mathrm{a}$ & $75.6 \mathrm{a}$ \\
\hline Significance $^{\mathrm{z}}$ & $* * *$ & $* *$ & $*$ & $* * *$ & $* * *$ & $* * *$ & $* * *$ & $* * *$ & $*$ & $* * *$ & * & $* *$ & $* * *$ & $* *$ & $* * *$ \\
\hline
\end{tabular}

z*,**,***Significant at $P \leq 0.05,0.01$, and 0.001 , respectively. Different letters within each column indicate significant differences according to Duncan's multiple range test $(P=0.05)$. 
Cassia anguxtifolia Mill. (Arshi et al., 2005)]. Differently, in this study, proline content increased with salinity independently of the salt source. This result suggested that $\mathrm{Ca}$ addition did not help to overcome the negative osmotic effects through proline accumulation.

Mineral analysis results supported the hypothesis that the highest biomass reduction in T5 treatment was mainly the result of the ionic effect of salinity. The highest concentration of $\mathrm{Na}$ ion and the nutritional imbalance associated with a reduction of $\mathrm{K}$ and $\mathrm{Ca}$ content were detected in $\mathrm{T} 5$ treatment. It is well known that high concentrations of $\mathrm{Na}$ and $\mathrm{Cl}$ can depress nutrient uptake and produce an extreme ratio of $\mathrm{Na} / \mathrm{Ca}$ and $\mathrm{Na} / \mathrm{K}$. High concentration of $\mathrm{Na}$ reduced the availability and uptake of $\mathrm{Ca}$ as a result of the antagonistic interaction, precipitation, and increases in ionic strength (Cramer, 1992; Rengel, 1992).

The partial replacement of $\mathrm{NaCl}$ with $\mathrm{CaCl}_{2}$ in the solution improved the nutritional status of cardoon leaves. Calcium content in cardoon leaves was enhanced by equimolar solutions containing $\mathrm{CaCl}_{2}$, and $\mathrm{K}$ depletion and $\mathrm{Na}$ accumulation were reduced in comparison with the solutions without $\mathrm{CaCl}_{2}$.

Potassium uptake was also reduced by a high level of $\mathrm{Na}$ as a result of competition and loss of membrane integrity and selectivity (Grattan and Grieve, 1999). Potassium depletion was greater in cardoon plants treated with $\mathrm{NaCl}$ than with $\mathrm{NaCl}+\mathrm{CaCl}_{2}$ at both iso-molar levels. A possible explanation is that additional $\mathrm{Ca}$ helped to maintain $\mathrm{K}$ uptake,

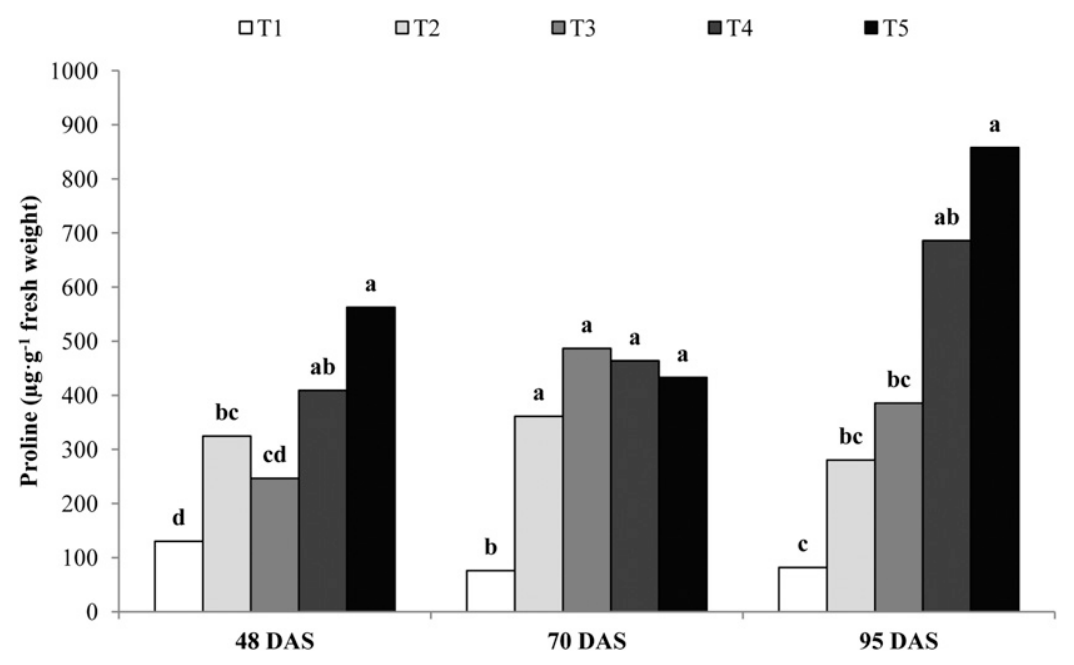

Fig. 1. Effects of saline treatments on proline content in leaves of cardoon at 48, 70, and $95 \mathrm{~d}$ after sowing (DAS). Different letters within the five columns indicate differences according to Duncan's test $(P=0.05)$.

counteracting the $\mathrm{K} / \mathrm{Na}$ competition effect. The presence of a high level of $\mathrm{Ca}$ in the solution influences the $\mathrm{K} / \mathrm{Na}$ selectivity by shifting the uptake ratio in favor of $\mathrm{K}$ at the expense of $\mathrm{Na}$. Moreover, Ca preserves membrane integrity and then leads to the reduction of $\mathrm{K}$ leakage from root cells (Grattan and Grieve, 1999). K uptake was negatively affected by $\mathrm{NaCl}$ salinity in our previous study on cardoon (Borgognone et al., 2013) and in a number of plant species such as maize (Zea mays L.) (Akram, 2014), cucumber (Cucumis sativus L.), and melon (Cucumis melo L.) (Rouphael et al., 2012a). The positive role of $\mathrm{Ca}$ on improving $\mathrm{K}$ content in plant tissues has been reported in Arabidopsis thaliana where $10 \mathrm{~mm}$ of $\mathrm{CaCl}_{2}$ completely prevented salt-induced $\mathrm{K}$ efflux from both roots and leaves (Shabala et al., 2006).

Antagonism between uptake of $\mathrm{NO}_{3}$ and $\mathrm{Cl}$ was also observed in cardoon plants subjected to salt stress. Nitrate depletion and $\mathrm{Cl}$ ion accumulation could have contributed to the growth reduction induced by saline treatments. $\mathrm{NO}_{3} / \mathrm{Cl}$ interactions are reported to be analogous to $\mathrm{K} / \mathrm{Na}$ interactions and selectivity (Teakle and Tyerman, 2010). Above that, salinity can also depress $\mathrm{NO}_{3}$ xylem transport rate and $\mathrm{NO}_{3}$ reduction rate in leaves with a consequent reduction of $\mathrm{NO}_{3}$ uptake, as demonstrated in a study with salt-sensitive bean (Phaseolus vulgaris L.) and salt-tolerant cotton (Gossypium hirsutum L.) (Gouia et al., 1994).

Chloride concentration was higher than $\mathrm{Na}$ concentration in leaves, indicating the inability of cardoon to restrict $\mathrm{Cl}$ uptake. In some plant species, the uptake and transport of $\mathrm{Cl}$ appeared to be less controlled than of $\mathrm{Na}$ (Alaoui-Sossé et al., 1998) as observed in cucumber (Colla et al., 2012, 2013a) and in red-osier dogwood (Cornus sericea L.). The critical toxicity concentration of $\mathrm{Cl}$ in leaf

Table 4. Effects of saline treatments on total phenols, total flavonoids, and antioxidant activity (FRAP) in leaves of cardoon at 48, 70, and 95 d after sowing (DAS).

\begin{tabular}{|c|c|c|c|c|c|c|c|c|c|}
\hline \multirow[b]{2}{*}{ Treatment } & \multicolumn{3}{|c|}{$\begin{array}{c}\text { Total phenols } \\
\text { (mg gallic acid/g dry wt) }\end{array}$} & \multicolumn{3}{|c|}{$\begin{array}{c}\text { Total flavonoids } \\
\text { (mg quercitin/g dry wt) }\end{array}$} & \multicolumn{3}{|c|}{$\begin{array}{c}\text { FRAP } \\
\left(\mu \mathrm{mol} \mathrm{FeSO}_{4} / \mathrm{g} \text { dry wt }\right)\end{array}$} \\
\hline & $48 \mathrm{DAS}$ & 70 DAS & $95 \mathrm{DAS}$ & $48 \mathrm{DAS}$ & 70 DAS & $95 \mathrm{DAS}$ & $48 \mathrm{DAS}$ & $70 \mathrm{DAS}$ & 95 DAS \\
\hline T1 & $12.3 \mathrm{c}$ & $11.8 \mathrm{~b}$ & $10.4 \mathrm{~b}$ & $5.0 \mathrm{c}$ & $15.4 \mathrm{~b}$ & $7.8 \mathrm{c}$ & $147.9 \mathrm{c}$ & $135.2 \mathrm{~b}$ & $143.7 \mathrm{~b}$ \\
\hline $\mathrm{T} 2$ & $16.9 \mathrm{ab}$ & $18.7 \mathrm{a}$ & $14.2 \mathrm{a}$ & $22.4 \mathrm{~b}$ & $34.4 \mathrm{a}$ & $18.1 \mathrm{ab}$ & $208.0 \mathrm{ab}$ & $255.0 \mathrm{a}$ & $216.8 \mathrm{a}$ \\
\hline T3 & $17.5 \mathrm{a}$ & $18.7 \mathrm{a}$ & $13.6 \mathrm{a}$ & $31.0 \mathrm{a}$ & $34.8 \mathrm{a}$ & $16.1 \mathrm{ab}$ & $226.0 \mathrm{a}$ & $233.4 \mathrm{a}$ & $193.1 \mathrm{a}$ \\
\hline $\mathrm{T} 4$ & $14.6 \mathrm{bc}$ & $17.1 \mathrm{a}$ & $13.8 \mathrm{a}$ & $16.0 \mathrm{~b}$ & $31.2 \mathrm{a}$ & $14.2 \mathrm{~b}$ & $187.0 \mathrm{~b}$ & $268.3 \mathrm{a}$ & $198.4 \mathrm{a}$ \\
\hline $\mathrm{T} 5$ & $15.5 \mathrm{ab}$ & $15.9 \mathrm{a}$ & $15.1 \mathrm{a}$ & $23.5 \mathrm{ab}$ & $27.2 \mathrm{a}$ & $19.6 \mathrm{a}$ & $194.2 \mathrm{~b}$ & $210.7 \mathrm{a}$ & $232.6 \mathrm{a}$ \\
\hline Significance $^{z}$ & $* *$ & $* *$ & $* * *$ & $* * *$ & $*$ & $* * *$ & $* * *$ & $* *$ & $* * *$ \\
\hline
\end{tabular}

${ }^{2 *}, * *, * *$ Significant at $P \leq 0.05,0.01$, and 0.001 , respectively. Different letters within each column indicate significant differences according to Duncan's multiple range test $(P=0.05)$.

Table 5. Effects of saline treatments on caffeoylquinic derivatives in leaves of cardoon at 48, 70, and 95 d after sowing (DAS).

\begin{tabular}{|c|c|c|c|c|c|c|c|c|c|}
\hline \multirow[b]{2}{*}{ Treatment } & \multicolumn{3}{|c|}{$\begin{array}{c}\text { Caffeic acid } \\
\left(\mathrm{mg} \cdot \mathrm{kg}^{-1} \text { dry wt }\right)\end{array}$} & \multicolumn{3}{|c|}{$\begin{array}{l}\text { Chlorogenic acid } \\
\left(\mu \mathrm{g} \cdot \mathrm{kg}^{-1} \text { dry wt) }\right.\end{array}$} & \multicolumn{3}{|c|}{$\begin{array}{c}\text { Cynarin } \\
\left(\mu \mathrm{g} \cdot \mathrm{kg}^{-1} \text { dry wt }\right)\end{array}$} \\
\hline & 48 DAS & 70 DAS & 95 DAS & 48 DAS & $70 \mathrm{DAS}$ & 95 DAS & $48 \mathrm{DAS}$ & 70 DAS & 95 DAS \\
\hline T1 & $3.0 \mathrm{~b}$ & $6.7 \mathrm{~b}$ & $5.5 \mathrm{~b}$ & $1.2 \mathrm{~b}$ & $1.4 \mathrm{~b}$ & $1.1 \mathrm{c}$ & $0.8 \mathrm{~b}$ & $1.3 \mathrm{~b}$ & $0.8 \mathrm{c}$ \\
\hline $\mathrm{T} 2$ & $8.9 \mathrm{~b}$ & $10.4 \mathrm{~b}$ & $6.9 \mathrm{~b}$ & $3.7 \mathrm{a}$ & $4.4 \mathrm{a}$ & $4.8 \mathrm{ab}$ & $2.2 \mathrm{a}$ & $3.6 \mathrm{a}$ & $3.2 \mathrm{~b}$ \\
\hline T3 & $10.6 \mathrm{ab}$ & $11.8 \mathrm{~b}$ & $7.4 \mathrm{~b}$ & $3.9 \mathrm{a}$ & $4.3 \mathrm{a}$ & $3.4 \mathrm{~b}$ & $2.5 \mathrm{a}$ & $4.7 \mathrm{a}$ & $2.8 \mathrm{~b}$ \\
\hline $\mathrm{T} 4$ & $8.4 \mathrm{~b}$ & $13.5 \mathrm{~b}$ & $8.9 \mathrm{~b}$ & $3.5 \mathrm{a}$ & $6.1 \mathrm{a}$ & $5.4 \mathrm{a}$ & $2.2 \mathrm{a}$ & $5.0 \mathrm{a}$ & $3.2 \mathrm{~b}$ \\
\hline $\mathrm{T} 5$ & $20.9 \mathrm{a}$ & $30.1 \mathrm{a}$ & $17.9 \mathrm{a}$ & $3.3 \mathrm{a}$ & $4.5 \mathrm{a}$ & $5.1 \mathrm{a}$ & $2.3 \mathrm{a}$ & $5.0 \mathrm{a}$ & $4.2 \mathrm{a}$ \\
\hline Significance $^{\mathrm{z}}$ & $*$ & $* *$ & $* *$ & $* * *$ & $* *$ & $* * *$ & $* *$ & $* *$ & $* * *$ \\
\hline
\end{tabular}

z*,**,***Significant at $P \leq 0.05,0.01$ and 0.001 , respectively. Different letters within each column indicate significant differences according to Duncan's multiple range test $(P=0.05)$. 

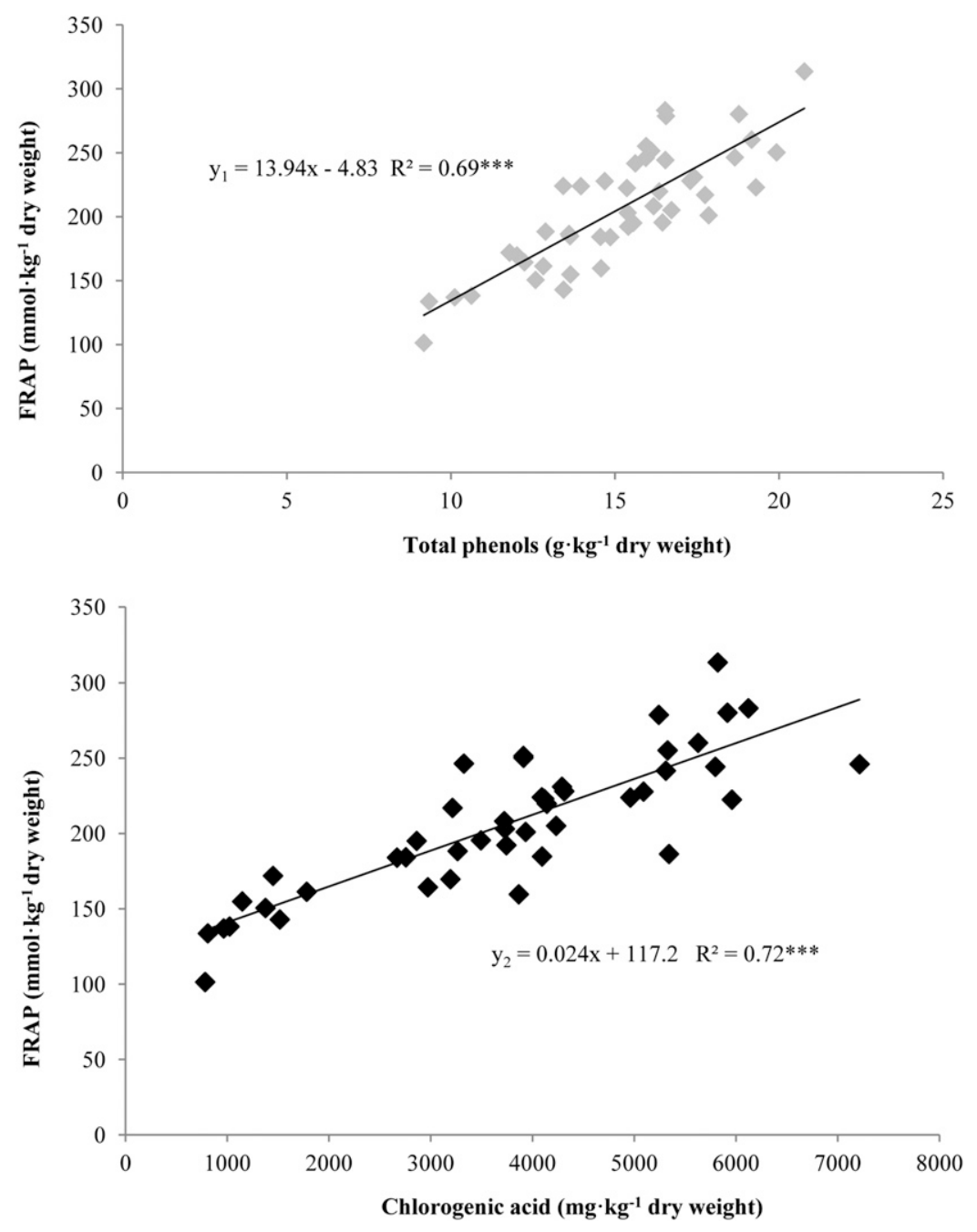

Fig. 2. Relationships between total phenols and antioxidant activity (FRAP) and between chlorogenic acid and FRAP in cardoon leaves. ${ }^{* * *}$ Significant at $P \leq 0.001$.

tissues is from 4 to 7 and from 15 to $50 \mathrm{~g} \cdot \mathrm{kg}^{-1}$ dry weight for $\mathrm{Cl}$-sensitive and Cl-tolerant plant species, respectively (Xu et al., 2000). In this study, $\mathrm{Cl}$ content in leaves of cardoon plants grown under saline conditions was beyond the critical limit of $50 \mathrm{~g} \cdot \mathrm{kg}^{-1}$ dry weight reported for salt-tolerant crops such as cardoon (Ksouri et al., 2012). However, the decrease of cardoon biomass was more related to the variation of $\mathrm{Na}$ content in leaves than of $\mathrm{Cl}$ content, which was similar among salt treatments. The use of $\mathrm{Ca}\left(\mathrm{NO}_{3}\right)_{2}$ instead of $\mathrm{CaCl}_{2}$ could be also explored to counteract the impact of salinity matching the beneficial effect of $\mathrm{Ca}$ and of $\mathrm{NO}_{3}$ vs. $\mathrm{Cl}$. In strawberry under saline conditions, foliar application of $\mathrm{Ca}\left(\mathrm{NO}_{3}\right)_{2}$ was found to reduce the negative effect of $\mathrm{NaCl}$ on plant growth and uptake of calcium and nitrate (Kaya et al., 2002).

Nutraceutical value of leaves. Chlorogenic acid and cynarin were the most abundant caffeoylquinc derivatives in cardoon leaves, whereas among target flavonoids, the highest content was detected for luteolin. The high presence of bioactive compounds was previously observed in leaves of cardoon cv. Bianco Avorio grown in a floating system, where, similarly, chlorogenic acid, cynarin, and luteolin were the most abundant compounds (Borgognone et al., 2013; Colla et al., 2013b; Rouphael et al., 2012b).

Nutraceutical properties of cardoon can be mainly ascribed to a synergistic effect of several active polyphenolic compounds and their antioxidant activity (Lattanzio et al., 2009). Relationships between the antioxidant compounds and antioxidant activity in cardoon leaves were studied for identifying the main polyphenolic compounds responsible of the antioxidant activity. Total phenols and chlorogenic acid showed a significant correlation with FRAP values (Fig. 2), whereas no significant correlations were detected for caffeic acid, apigenin, and luteolin-7-glucoside (data not shown). FRAP assay, based on the ability of antioxidants to reduce $\mathrm{Fe}^{3+}-\mathrm{Fe}^{2+}$, measures the reducing capacity of a substrate and is commonly used to measure the total antioxidant capacity of food and plants (Pellegrini et al., 2003). Falleh et al. (2008) showed a highly significant correlation between phenolics and DPPH quenching activity in cardoon.

The high level of salinity stress induced by $60 \mathrm{~mm}$ of $\mathrm{NaCl}$ (T5) did not always match with a further increase of secondary metabolites with respect to the other saline treatments, except for caffeic acid at each harvest and cynarin at $95 \mathrm{DAS}$. At moderate salinity [25 to $50 \mathrm{~mm}$ of $\mathrm{NaCl}$ in cardoon (Hanen et al., 2008)], plant growth can be reduced more than photosynthesis; thus, the plant diverts the synthesis of carbohydrates to produce secondary metabolites. When salinity is higher, also photosynthesis can decline; therefore, growth and production of polyphenols will be decreased even further (Rezazadeh et al., 2012). A decline of polyphenols accumulation was observed with a soil salinity higher than $6.9 \mathrm{dS} \cdot \mathrm{m}^{-1}$ in Cynara scolymus L. (Rezazadeh et al., 2012) and with $15 \mathrm{~g} \cdot \mathrm{L}^{-1}$ of $\mathrm{NaCl}$ in Carthamus tinctorius L. (Salem et al., 2014).

The addition of both $\mathrm{NaCl}$ and $\mathrm{CaCl}_{2}$ (T2 and T4) did not affect polyphenol content in cardoon leaves compared with $\mathrm{NaCl}$ treatments (T3 and T5). This result agreed with a previous study (Borgognone et al., 2013) in which the increase of polyphenols in cardoon was similar using $\mathrm{NaCl}$ or $\mathrm{CaCl}_{2}$ as salinity sources.

\section{Conclusion}

The partial replacement of $\mathrm{NaCl}$ with $\mathrm{CaCl}_{2}$ mitigated the adverse effects of salinity on cardoon biomass production but only at the highest salinity level. $\mathrm{CaCl}_{2}$ was effective in improving nutritional status of leaves increasing $\mathrm{K}$ and $\mathrm{Ca}$ content and reducing $\mathrm{Na}$ accumulation, especially at 48 and 70 DAS

Nutraceutical value of cardoon biomass was increased by saline treatments, regardless of $\mathrm{CaCl}_{2}$ addition. Results showed that the antioxidant activity of cardoon leaves was improved by salinity as a result of the increase of total phenols and chlorogenic acid contents in leaves.

\section{Literature Cited}

Akram, M. 2014. Effect of nitrogen on solute accumulation and ion contents of maize under sodium chloride stress. Comm. Soil Sci. Plant 45:86-100

Alaoui-Sossé, B., L. Sehmer, P. Barnola, and P. Dizengremel. 1998. Effect of $\mathrm{NaCl}$ salinity on growth and mineral partitioning in Quercus robur L., a rhythmically growing species. Trees-Struct. Funct. 12:424-430.

Arshi, A., M.Z. Abdin, and M. Iqbal. 2005. Ameliorative effects of $\mathrm{CaCl} 2$ on growth, ionic relations, and proline content of senna under salinity stress. J. Plant Nutr. 28:101-125.

Arshi, A., A. Ahmad, I.M. Aref, and M. Iqbal. 2010. Effect of calcium against salinityinduced inhibition in growth, ion accumulation and proline content in Cichorium intybus L. J. Environ. Bio. 31:939-944.

Baghalian, K., A. Haghiry, M.R. Naghavi, and A. Mohammadi. 2008. Effect of saline irrigation water on agronomical and phytochemical characters of chamomile (Matricaria recutita $\mathrm{L}$.). Sci. Hort. 116:437-441.

Bates, L.S., R.P. Waldren, and I.N. Teare. 1973. Rapid determination of free proline for water stress studies. Plant Soil 39:205-208.

Borgognone, D., M. Cardarelli, E. Rea, L. Lucini, and G. Colla. 2013. Salinity source-induced 
changes in yield, mineral composition, phenolic acids and flavonoids in leaves of artichoke and cardoon grown in floating system. J. Sci. Food Agr. doi: 10.1002/jsfa.6403.

Bremner, J.M. 1965. Total nitrogen, p. 1149-1178. In: Black, C.A., D.D. Evans, I.L. White, L.E. Ensminger, and F.E. Clark (eds.). Methods of soil analysis. Agronomy monographs No. 9, Part 2.

Cardarelli, M., Y. Rouphael, E. Rea, L. Lucini, M. Pellizzoni, and G. Colla. 2013. Effects of fertilization, arbuscular mycorrhiza, and salinity on growth, yield, and bioactive compounds of two Aloe species. HortScience 48:568-575.

Cataldo, D.A., M. Haroon, L.E. Scrander, and V.L. Youngs. 1975. Rapid colorimetric determination of nitrate in plant tissue by nitration of salicylic acid. Commun. Soil Sci. Plant Anal. 6:71-80.

Colla, G., Y. Rouphael, R. Jawad, P. Kumar, E. Rea, and M. Cardarelli. 2013a. The effectiveness of grafting to improve $\mathrm{NaCl}$ and $\mathrm{CaCl}_{2}$ tolerance in cucumber. Sci. Hort. 164:380-391.

Colla, G., Y. Rouphael, M. Cardarelli, E. Svecova, E. Rea, and L. Lucini. 2013b. Effects of saline stress on mineral composition, phenolics acids and flavonoide in leaves of artichoke and cardoon genotypes grown in floating system. J. Sci. Food Agr. 93:1119-1127.

Colla, G., Y. Rouphael, E. Rea, and M. Cardarelli. 2012. Grafting cucumber plants enhance tolerance to sodium chloride and sulfate salinization. Sci. Hort. 135:177-185.

Cramer, G.R. 1992. Kinetics of maize leaf elongation. II Responses of a Na-excluding cultivar and a $\mathrm{Na}$-including cultivar to varying $\mathrm{Na} / \mathrm{Ca}$ salinities. J. Expt. Bot. 43:857-864.

Dominguez-Perles, R., M.C. Martinez-Ballesta, F. Riquelme, M. Carvajal, C. Garcia-Viguera, and D.A. Moreno. 2011. Novel varietis of broccoli for optimal bioactive components under saline stress. J. Sci. Food Agr. 91:1638-1647.

Dutta, R.K. and R.S. Maharia. 2012. Antioxidant response of some common medicinal plants grown in copper minimizing areas. Food Chem. 131:259-265.

Eaton, A.D., L.S. Clesceri, and A.E. Greenberg. 1995. Standard method for the examination of water and wastewater. $19^{\text {th }} \mathrm{Ed}$. American Public Health Assoc., Washington, DC. p. 66-71.

Falleh, H., R. Ksouri, K. Chaieb, N. KarrayBouraoui, N. Trabelsi, M. Boulaaba, and C. Abdelly. 2008. Phenol composition of Cynara cardunculus L. organs, and their biological activities. C. R. Biol. 331:372-379.

Fernández, J., M.D. Curt, and P.L. Aguado. 2006. Industrial applications of Cynara cardunculus L. for energy and other uses. Ind. Crops Prod. 24:222-229.

Girija, C., B.N. Smith, and P.M. Swamy. 2002. Interactive effects of sodium chloride and calcium chloride on the accumulation of proline and glycinebetaine in peanut (Arachis hypogaea L.). Environ. Expt. Bot. 47:1-10.

Gouia, H., M.H. Ghorbal, and B. Touraine. 1994. Effects of $\mathrm{NaCl}$ on flow of $\mathrm{N}$ and mineral ions and on $\mathrm{NO}_{3}{ }^{-}$reduction rate within whole plant of salt-sensitive bean and salt-tolerant cotton. Plant Physiol. 105:1409-1418.

Grattan, S.R. and C.M. Grieve. 1999. Salinitymineral nutrient relations in horticultural crops. Sci. Hort. 78:127-157.

Hanen, F., R. Ksouri, W. Megdiche, N. Trabelsi, M. Boulaaba, and C. Abdelly. 2008. Effect of salinity on growth, leaf phenolic content and antioxidant scavenging activity in Cynara cardunculus L, p. 335-343. In: Abdelli, C., M. Ozturk, M. Ashrafand, and Y.C. Grignin (ed.). Biosaline agriculture and high salinity tolerance. Birkhauser Verlag, Switzerland.

Karla, Y.P. 1998. Handbook of reference methods for plant analysis. CRC Press Inc., Boca Raton, FL. p. 165-170.

Kaya, C., B.E. Ak, D. Higgs, and B. MurilloAmador. 2002. Influence of foliar-applied calcium nitrate on strawberry plants grown under salt-stressed conditions. Austral. J. Expt. Agr. 42:631-636

Khayyat, M., S. Khanizadeh, E. Tafazoli, S. Rajaee, B. Kholdebarin, and Y. Emam. 2011. Effects of different calcium forms on gas exchange activities, water usage and macronutrient uptake by strawberry plants under sodium chloride stress. J. Plant Nutr. 34:427-435.

Ksouri, R., W.M. Ksouri, I. Jallali, A. Debez, C. Magné, I. Hiroko, and C. Abdelly. 2012. Medicinal halophytes: Potent source of health promoting biomolecules with medical, nutraceutical and food applications. Crit. Rev. Biotechnol. 32:289-326.

Kukíc, J., V. Popović, S. Petrović, P. Mucaji, A. Ćirić, D. Stojković, and M. Soković. 2008. Antioxidant and antimicrobial activity of Cynara cardunculus extracts. Food Chem. 107:861-868.

Lattanzio, V., P.A. Kroon, V. Linsalata, and A. Cardinali. 2009. Globe artichoke: A functional food and source of nutraceutical ingredients. J. Funct. Food 1:131-144.

Miccadei, S., D. Di Venere, A. Cardinali, F. Romano, A. Durazzo, M.S. Foddai, R. Fraioli, S. Mobarhan, and G. Maiani. 2008. Antioxidative and apoptotic properties of polyphenolic extracts from edible part of artichoke (Cynara scolymus L.) on cultured rat hepatocytes and on human hepatoma cells. Nutr. Cancer 60:276-283.

Munns, R. and M. Tester. 2008. Mechanisms of salinity tolerance. Annu. Rev. Plant Biol. 59: 651-681.

Nasir Khan, M., M.H. Siddiqui, F. Mohammad, M. Naeem, M. Masroor, and A. Khan. 2010. Calcium chloride and gibberellic acid protect linseed (Linum usitatissium L.) from $\mathrm{NaCl}$ stress by inducing antioxidative defence system and osmoprotectant accumulation. Acta Physiol. Plant. 32:121-132.

Navarro, J.M., C. Garrido, V. Martínez, and M. Carvajal. 2003. Water relation and xylem transport of nutrients in pepper plants grown under two different salt stress regimes. Plant Growth Regulat. 41:237-245.

Pandino, G., S. Lombardo, G. Mauromicale, and G. Williamson. 2011. Phenolic acids and flavonoids in leaf and floral stem of cultivated and wild Cynara cardunculus L. genotypes. Food Chem. 126:417-422.

Pellegrini, N., M. Serafini, B. Colombi, D. Del Rio, S. Salvatore, M. Bionache, and F. Brighenti. 2003. Total antioxidant capacity of plant foods, beverages and oils consumed in Italy assessed by three different in vitro assay. J. Nutr. 133:2812-2819.

Renault, S. and M. Affifi. 2009. Improving $\mathrm{NaCl}$ resistance of red-osier dogwood: Role of $\mathrm{CaCl}_{2}$ and $\mathrm{CaSO}_{4}$. Plant Soil 315:123-133.

Rengel, Z. 1992. The role of calcium in salt toxicity. Plant Cell Environ. 15:625-632.

Rezazadeh, A., A. Ghasemnezhad, M. Barani, and T. Telmadarrehei. 2012. Effect of salinity on phenolic composition and antioxidant activity of artichoke (Cynara scolymus L.) leaves. Res. J. Med. Plant 6:245-252.

Rouphael, Y., M. Cardarelli, E. Rea, and G. Colla. 2012a. Improving melon and cucumber photosynthetic activity, mineral composition, and growth performance under salinity stress by grafting onto Cucurbita hybrid rootstocks. Photosynthetica 50:180-188.

Rouphael, Y., M. Cardarelli, L. Lucini, E. Rea, and G. Colla. 2012b. Nutrient solution concentration affects growth, mineral composition, phenolic acids, and flavonoid in leaves of artichoke and cardoon. HortScience 47:1424-1429.

Salem, N., K. Msaada, W. Dhifi, F. Limam, and B. Marzouk. 2014. Effect of salinity on plant growth and biological activities of Carthamus tinctorius L. extracts at two flowering stages. Acta Physiol. Plant. 36:433-445.

Shabala, S., V. Demidchik, L. Shabala, A. Cuint, S.J. Smith, A.J. Miller, J.M. Davies, and I.A. Newman. 2006. Extracellular $\mathrm{Ca}^{2+}$ ameliorates $\mathrm{NaCl}$-induced $\mathrm{K}^{+}$loss from Arabidopsis root and leaf cells by controlling plasma membrane $\mathrm{K}^{+}$-permeable channels. Plant Physiol. 141:16531665.

Silva, C., V. Martínez, and M. Carvajal. 2008. Osmotic versus toxic effects of $\mathrm{NaCl}$ on pepper plants. Biol. Plant. 52:72-79.

Singleton, V.L. and J.A. Rossi. 1965. Colorimetry of total phenolics with phosphomolybdicphosphotungstic acid reagent. Amer. J. Enol. Viticult. 16:144-158.

Sreenivasulu, N., B. Grimm, U. Wobus, and W. Weschke. 2000. Differential response of antioxidant compounds to salinity stress in salttolerant and salt-sensitive seedlings of foxtail millet (Setaria italica). Physiol. Plant. 109: 435-442.

Teakle, N.L. and S.D. Tyerman. 2010. Mechanism of Cl-transport contributing to salt tolerance. Plant Cell Environ. 33:566-589.

Veríssimo, P., C. Esteves, C. Faro, and E. Pires. 1995. The vegetable rennet of Cynara cardunculus L. contains two proteinases with chymosin and pepsin-like specificities. Biotechnol. Lett. 17:621-626.

$\mathrm{Xu}$, G., H. Magen, J. Tarchizky, and U. Kafkafi. 2000. Advances in chloride nutrition. Adv. Agron. 68:96-150. 